\title{
Influencing Factors of Social Anxiety and Emotional Maturity among Adolescents
}

\author{
Dr. S Gayatridevi ${ }^{1 *}$, Ms. Anu Vincent ${ }^{2}$
}

\section{ABSTRACT}

The current study deals with the emotional maturity and social anxiety among adolescents. One hundred and seventy subjects (Boys $=90$, Girls $=80$ ) from GRD College of Arts and Science, Coimbatore, were selected for the study. The Psychological Tests such as Case Study Schedule (Gayatridevi and Anu), Emotional Maturity Scale (Hemalatha) and Liebowitz Social Anxiety Scale (Michael R. Liebowitz) were administered to the subjects. The data was analyzed by using SPSS + PC package for $\mathrm{t}$-test was computed. The results revealed that adolescent girls experienced more social anxiety than boys $(M=66.46)$. Gender and family size had no significant effect on emotional maturity. There was no significant relationship found between the emotional maturity and social anxiety.

Keywords: Influencing Factors, Social Anxiety, Emotional Maturity, Adolescents

"He dare not come in company, for here he should be misused, disgraced, overshoot himself in gesture or speeches or be sick; he thinks everyman observes him".

-Richard Burton

Social anxiety is one of the most common psychological disorders among school aged children and adolescents in India. Social anxiety is associated with substantial negative effects on children's social, emotional and academic success.

Social anxiety is the anxiety about social situations, interactions with others, and being evaluated or scrutinized by other people (Leitenberg, 1990). Social Phobia or Social Anxiety Disorder is a psychopathological form of social anxiety and is a chronic problem that can result in a reduced quality of life (Leitenberg, 1990).Social anxiety is the fear of social situations and the interaction with other people that can automatically bring on feelings of self-consciousness, judgement,

\footnotetext{
${ }^{1}$ Assistant Professor (SG), Department of Psychology, Avinashilingam Institute of Home Science and Higher Education for Women, India

${ }^{2}$ Department of Psychology, Avinashilingam Institute of Home Science and Higher Education for Women, India *Responding Author

(C) 2016, S Gayatridevi, A Vincent; licensee IJIP. This is an Open Access Research distributed under the terms of the Creative Commons Attribution License (http://creativecommons.org/licenses/by/2.0), which permits unrestricted use, distribution, and reproduction in any Medium, provided the original work is properly cited.
} 


\section{Influencing Factors of Social Anxiety and Emotional Maturity among Adolescents}

evaluation, and inferiority. It is the fear and anxiety of being judged and evaluated negatively by other people, leading to feelings of inadequacy, embarrassment, humiliation and depression (Richard, 2000).

\section{Genetic and Family Factors}

There are two to threefold greater risk of having social phobia if a first-degree relative also has the disorder. This could be due to genetic or due to children acquiring social fears and avoidance through processes of observational learning or parental psychosocial education (Kendler, Karkowski and Prescott, 1999).

Adolescents who were rated as having an insecure (anxious-ambivalent) attachment with their mother as infants were twice as likely to develop anxiety disorders by late adolescence, including Social Phobia (Warren, Huston, Egeland and Sroufe, 1997).

\section{Cultural Influences}

Cultural factors that have been related to Social Anxiety Disorder include a society's attitude towards shyness and avoidance, affecting ability to form relationships or access employment or education and shame (Okano, 1994).

Purely demographic variables may also play a role. There are possibly lower rates of Social Anxiety Disorder in Mediterranean Countries and higher rates in Scandinavian Countries. Problems in developing social skills, or 'social effectiveness', may be a cause of some Social Anxiety Disorder, through either inability or lack of confidence to interact socially and gain positive reactions and acceptance from others. The socially anxious one's perceive their own social skills to be low (Segrin and Kinney, 2005).

The road to emotional maturity involves the integration of various aspects of personality into the self. Emotional maturity is a balance between the brain and the emotions, between the inner and outer world of the individual (Landau, 1998).

Emotional maturity can be understood in terms of ability of self-control, which in turn is a result of thinking and learning. An emotionally matured person is one whose emotional life is well under control (Chamberlain, 1960).

\section{Causes of Emotional Immaturity}

When mental illness is at play, medication can make a marked difference in a person's ability to maturely cope with difficult situations and interact productively with others (Pearson, 2005).

Child Abuse: People who were physically, sexually or emotionally abused often exhibit emotional immaturity. 
Fetal Alcohol Syndrome: Fetal alcohol syndrome is directly linked to emotional immaturity in children and adults.

Other Medical Conditions: Emotional immaturity can be caused by Autism, Asperger's syndrome, Cognitive problems, Brain damage, Learning disabilities, Depression and Anxiety disorders.

Trauma: Individuals who suffer traumas as children and teens including rape and serious illnesses often display emotional immaturity later in life.

Parenting Issues: Children those are experienced less freedom and responsibilities at home lead to emotional immaturity. People whose parents were too controlling often show signs of emotional immaturity later in life.

Thus the present study aims to study the adolescent girls and boys who experience more social anxiety. As well as a Gender and family size effect on emotional maturity is also envisaged.

\section{METHOD}

\section{Objectives}

1. To compare the level of Social Anxiety and Emotional Maturity in adolescent boys and girls

2. To identify the influence of family size on emotional maturity and social anxiety.

3. To identify the level of Social Anxiety and Emotional Maturity among adolescent boys and girls

4. To find out the relationship between Emotional Maturity and Social Anxiety

Null Hypotheses

1. There is no marked difference in the level of Social Anxiety and Emotional Maturity in adolescent boys and girls.

2. There is no marked difference in the level of Social Anxiety and Emotional Maturity based on the family size.

3. There are no symptoms of Social Anxiety and Emotional maturity in adolescent boys and girls

4. There is no relationship between Emotional Maturity and Social Anxiety.

\section{Sample}

One hundred and seventy adolescent boys and girls (Boys $=90$ and Girls $=80$ ) from the GRD College of Arts and Science were selected to serve as the sample. They were in the age range of 18 - 20 years.

\section{Tools and Techniques}

The needed information from the sample was collected through the method of Case study and Psychological testing. Case Study Schedule developed by Dr. S. Gayatridevi and Anu Vincent (2011) was used to get the information about the demographic details, type of family, family size, negative emotions, and about their social skills and level of emotional maturity. 
The Emotional Maturity Scale (EMS) developed by Dr. Hemalatha Natesan, Professor (Retired), Head of the Department, Psychology (1989) was used to assess the level of emotional maturity among adolescents. This scale consists of 45 items that measures the emotional maturity. It was five point Likert's scale with following rating options1.Always, 2.Almost always, 3.Sometimes, 4.Rarely, 5.Never. The reliability and validity scores are 0.82 and 0.72 respectively.

The Liebowitz Social Anxiety Scale (LSAS) developed by Dr. Michael R. Liebowitz (1987) was used to assess the level of social anxiety among adolescents. The scale features 24 items, 13 relating to performance anxiety and 11 concerning social situations. This rates fear/anxiety and avoidance on 24 commonly feared situations. The students were asked to answer two questions for each item. The first question relating to how much they fear the situation, based on four options. The options are as follows: 0-None, 1- Mild, 2-Moderate, 3-Severe. The second question relating to how much they avoid the situation, based on four options. The options are as follows: 0 -Never, 1-Occassionally, 2-Often, 3-Usually. The reliability and validity scores are 0.94 and 0.72 respectively.

\section{RESULTS}

Data was analyzed by using SPSS + PC package and ANOVA and $t$ - test statistics technique were used.

Table - I Difference between the Mean values of Emotional Maturity among Boys and Girls

\begin{tabular}{|l|c|c|c|c|c|}
\hline \multicolumn{1}{|c|}{ Variable } & Gender & Number & Mean & $\begin{array}{c}\text { Standard } \\
\text { Deviation }\end{array}$ & t \\
\hline $\begin{array}{l}\text { Emotional } \\
\text { Maturity Scale }\end{array}$ & Boys & 90 & 130.98 & 17.77 & \\
\cline { 2 - 6 } & Girls & 80 & 134.01 & 14.80 & 1.20 NS \\
\hline
\end{tabular}

NS = Not significant

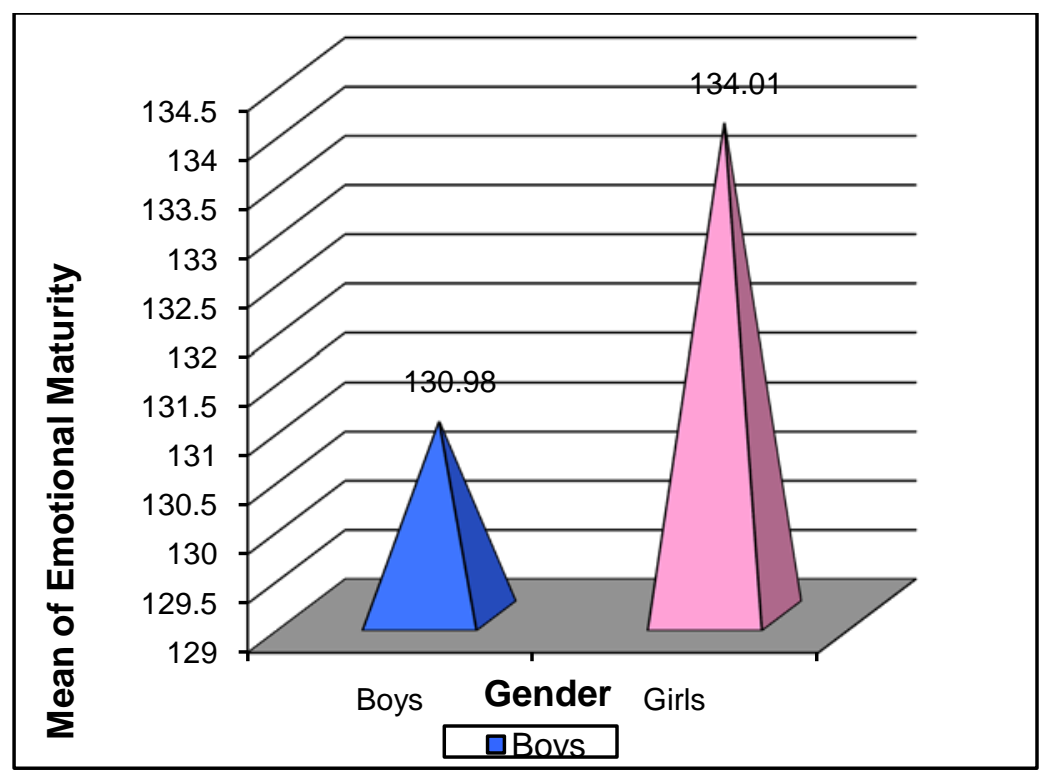

Figure - I Difference between the Mean values of Emotional Maturity among Boys and Girls

(c) The International Journal of Indian Psychology, ISSN 2348-5396 (e)| ISSN: 2349-3429 (p) | 64 
Table I shows the difference between the mean values of emotional maturity of boys and girls. The mean scores are 130.98 and 134.01 for boys and girls respectively and there was no significant difference. This supports the null hypothesis that there will be no marked difference in the emotional maturity of boys and girls. However, females had slightly higher emotional maturity than males. According to Boyd and Huffman (1984) the relationship between emotional maturity and drinking-and-driving involvement among young adults' girls and boys in the same age group, girls were more emotionally mature than boys. This helps the females to have more adjustment when compared to males.

Table - II Difference between the Mean Values of Emotional Maturity Based On the Family Size

\begin{tabular}{|c|c|c|c|c|c|}
\hline Variable & $\begin{array}{c}\text { Number of } \\
\text { Members in the } \\
\text { Family }\end{array}$ & Number & Mean & $\begin{array}{c}\text { Standard } \\
\text { Deviation }\end{array}$ & t \\
\hline $\begin{array}{c}\text { Emotional } \\
\text { Maturity } \\
\text { Scale }\end{array}$ & Up to 4 & 121 & 132.74 & 16.37 & 0.41 NS \\
\hline
\end{tabular}

NS=Not significant

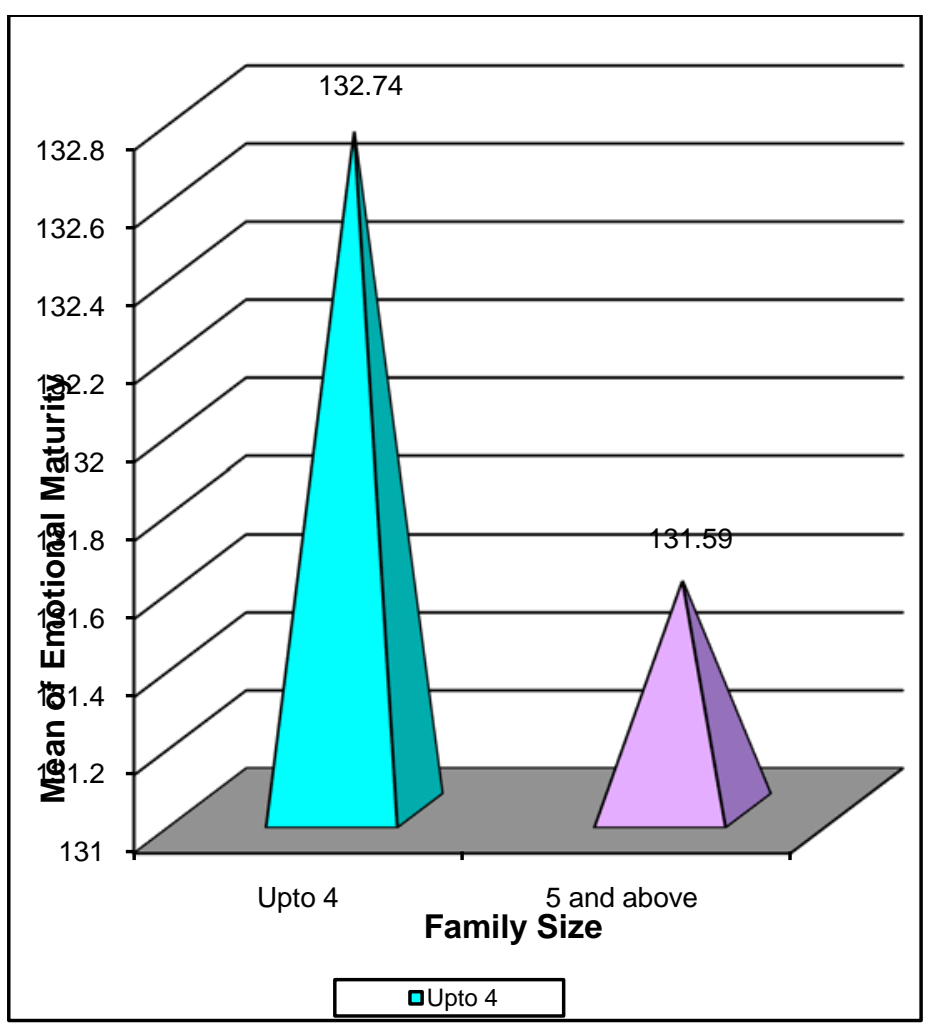

Figure II Difference between the Mean Values of Emotional Maturity Based On the Family Size

(C) The International Journal of Indian Psychology, ISSN 2348-5396 (e)| ISSN: 2349-3429 (p) | 65 
Table II shows the difference between the mean values of emotional maturity based on the family size. The mean scores are 132.74 and 131.59 for "up-to 4" and " 5 and above" categories respectively and there was no significant difference. Since the results were not significant, it indicated that number of members does not have any influence on one's emotional maturity. The reason may be attributed to the child rearing practices employed by the parents and the social environment where the children were reared.

Table - III Difference between the Mean values of Social Anxiety of Boys and Girls

\begin{tabular}{|c|c|c|c|c|c|}
\hline Variable & Gender & Number & Mean & $\begin{array}{c}\text { Standard } \\
\text { Deviation }\end{array}$ & t \\
\hline $\begin{array}{c}\text { Social Anxiety } \\
\text { Scale }\end{array}$ & Boys & 90 & 48.68 & 17.25 & $6.08^{*}$ \\
\hline
\end{tabular}

* Significant at 0.01 level

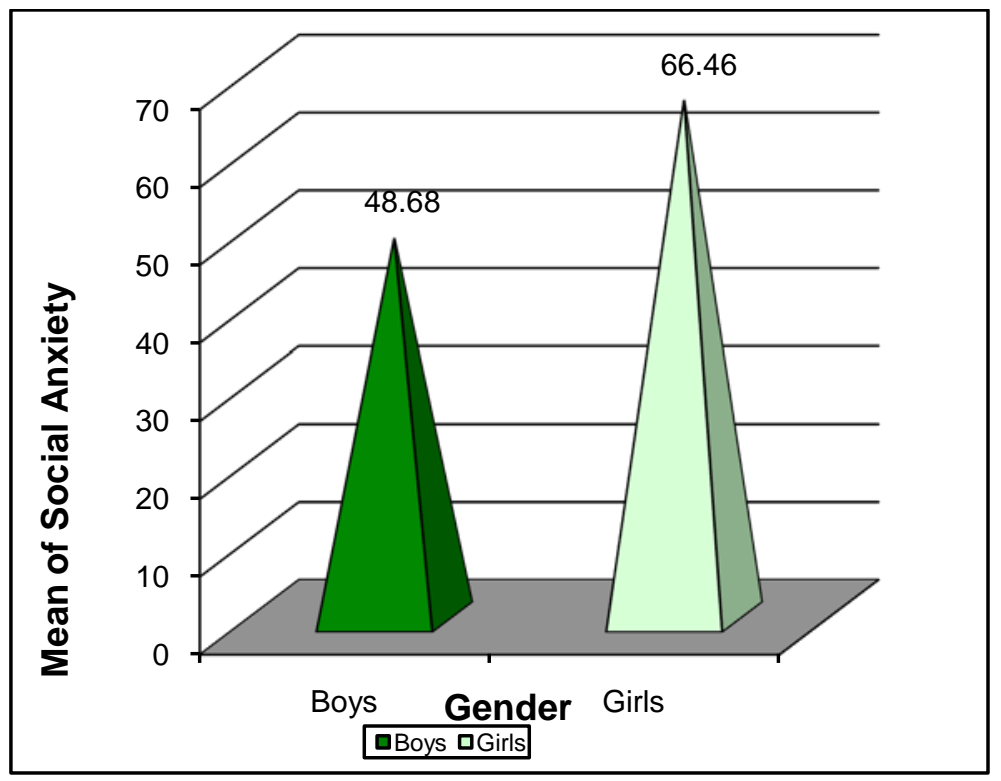

Figure III Difference between the Mean values of Social Anxiety of Boys and Girls

Table III shows the difference between the mean values of social anxiety of boys and girls. The mean scores were 48.68 and 66.46 for boys and girls respectively and there difference was significant at 0.01 levels. There was a marked difference in the level of social anxiety in boys and girls, which opposes the null hypothesis. The result indicated that girls have more social anxiety than boys. This is in line with the study conducted by Lopez, Ingles and Fernandez (2004) on gender and age differences in the assessment of social fears in adolescence. The result indicated that girls exhibited significantly higher levels of social anxiety than boys. The girls reported more avoidance of social situations than boys. The reason may be attributed to the sexrole socialization process. Boys were expected to engage in social situations and follow the traditional male sex-role, so social avoidance was not reinforced.

(c) The International Journal of Indian Psychology, ISSN 2348-5396 (e)| ISSN: 2349-3429 (p) | 66 
A study conducted by Wittchen, Stein and Kessler (1999) on prevalence of social fears and social phobia in a community sample of adolescents and young adults, it was found that lifetime prevalence of social phobia was $9 \pm 5 \%$ in females and $4 \pm 9 \%$ in males. It was found to be quite prevalent in $14 \pm 24$ year-olds.

The reason for high social phobia can be attributed to the fluctuations of hormones as given in the study conducted by Weinstock (1999) on gender differences in the presentation and management of Social Anxiety Disorder. The lifetime prevalence rate is $13.3 \%$, with rates of $15.5 \%$ in women and $11.1 \%$ in men. The results revealed that gender differences were influenced by the fluctuations in the levels of endogenous or exogenous reproductive hormones. Neurotransmitter systems implicated in the etiology of mood and anxiety disorders were affected by both estrogen and progesterone. There were also issues with regard to pregnancy in women who had Social Anxiety Disorder. Therefore treatment strategies for patients with Social Anxiety Disorder should consider gender differences in response to pharmacotherapy, psychiatric co morbidity, oral contraceptive use, pregnancy status, and the specific nature of symptoms in the individual patient.

Table - IV Difference between the Mean values of Social Anxiety Based on the Family Size

\begin{tabular}{|c|c|c|c|c|c|}
\hline Variable & $\begin{array}{c}\text { Number of } \\
\text { Members in the } \\
\text { Family }\end{array}$ & Number & Mean & $\begin{array}{c}\text { Standard } \\
\text { Deviation }\end{array}$ & $\mathrm{t}$ \\
\hline $\begin{array}{c}\text { Social Anxiety } \\
\text { Scale }\end{array}$ & Upto 4 & 121 & 57.16 & 21.15 & \\
\hline
\end{tabular}

NS=Not significant

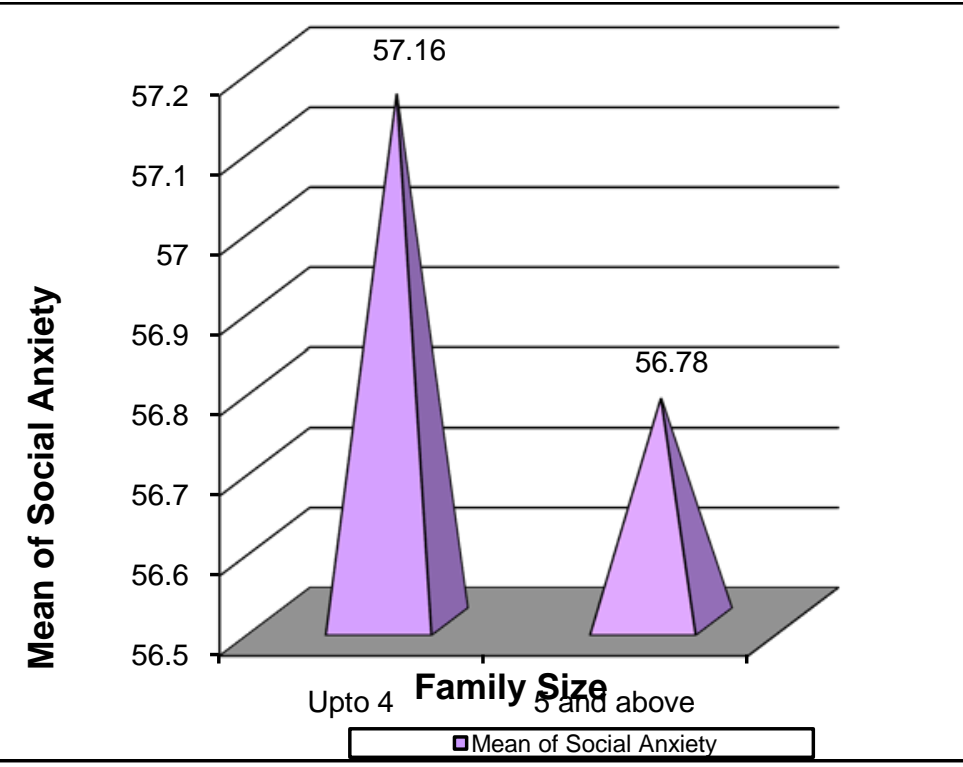

Figure IV Difference between the Mean values of Social Anxiety Based on the Family Size

(C) The International Journal of Indian Psychology, ISSN 2348-5396 (e)| ISSN: 2349-3429 (p) | 67 


\section{Influencing Factors of Social Anxiety and Emotional Maturity among Adolescents}

Table IV shows the difference between the mean values of social anxiety based on the family size. The mean scores are 57.16 and 56.78 for "up-to 4" and " 5 and above categories" respectively and it was not significant. This supports the null hypothesis that family size has no effect on social anxiety. Social anxiety or socializing skills were not affected or influenced by family members.

Table V Correlation between Emotional Maturity and Social Anxiety among Adolescents Boys (n=90), Girls (n=80)

\begin{tabular}{|l|c|c|}
\hline \multicolumn{1}{|c|}{ VARIABLE } & MEAN & R \\
\cline { 1 - 2 } Emotional maturity & 133.79 & \multirow{2}{*}{0.19} \\
\hline Social anxiety & 59.69 & \\
\hline
\end{tabular}

Table $\mathrm{V}$ shows the level of correlation between emotional maturity and social anxiety among adolescents. The correlation value is 0.19 . This indicates that there is no relationship between emotional maturity and social anxiety. This supports the null hypothesis that "there is no relationship between emotional maturity and social anxiety”.

From the tables presented above, it was found that there was a significant difference in the level of social anxiety among the adolescents. Adolescent girls were having more social anxiety than boys. However the family size did not affect the social anxiety of the subjects. The most feared or avoided social situations of the subjects were "trying to make someone's acquaintance for the purpose of a romantic/sexual relationship", "speaking up at the meeting" and "acting, performing, or speaking in front of an audience”. There was no significant difference in the emotional maturity of the subjects based on gender and family size. The study concluded that there was no relationship between emotional maturity and social anxiety among adolescent boys and girls.

\section{CONCLUSIONS}

Adolescent girls had more social anxiety than boys. There was no significant difference in the level of emotional maturity in the subjects. There was no significant difference in the level of emotional maturity and social anxiety in the subjects based on the family size. However, comparatively girls had slightly higher emotional maturity. There was no relationship between emotional maturity and social anxiety. The most feared or avoided situations of the subjects were "trying to make someone's acquaintance for the purpose of a romantic/sexual relationship", “speaking up at the meeting” and "acting, performing, or speaking in front of an audience”

\section{Acknowledgments}

The author appreciates all those who participated in the study and helped to facilitate the research process. 


\section{Conflict of Interests}

The author declared no conflict of interests.

\section{REFERENCES}

Boyd N. R. \& Huffman, W. J. (1984). The relationship between emotional maturity and drinkingand-driving involvement among young adults. Journal of Safety Research, 15 (1), 1-6.

Garcia-Lopez, L., Olivares, J., Beidel, D., Albano, A. M., Turner, S. \& Rosa, A. I. (2006). Efficacy of three treatment protocols for adolescents with social anxiety disorder: A 5year follow-up assessment. Anxiety disorders, 20 (6), 175-191. http://ujaen.academia.edu/LuisJoaquinGarciaLopez/Papers/90596/5-year_followup_social_anxiety

Kendler, K., Karkowski, L. \& Prescott, C. (1999). Fears and phobias: reliability and heritability. http://en.wikipedia.org/wiki/Social_anxiety_disorder\#cite_note-webmd.com-0

Landau, E. (1998). The Self - The Global Factor of Emotional Maturity. Roeper Review, 20. http://www.questia.com/googleScholar.qst;jsessionid=DFE771124C063576939221E6BD 47338A.inst3_3b?docId=5001378411

Leitenberg, H. (1990). Handbook of Social and Evaluation Anxiety. http://en.wikipedia.org/wiki/Social_anxiety\#cite_note-leitenberg-0

Okano, K. (1994). "Shame and social phobia: a transcultural viewpoint". Bull Menninger Clinic, 58 (3), 323-338.

http://enlight.lib.ntu.edu.tw/FULLTEXT/JR-MDL/oka.htm

Pearson, E. V. (2005). Causes of emotional immaturity. In ehow. Retrieved from http://www.ehow.com/facts_4914844_causes-emotional-immaturity.html

Richards, A. T. (1996). Definition of Social Anxiety. http://www.socialanxietyinstitute.org/define.html

Segrin, C. \& Kinneyl, T. (2005). Social skills deficits among the socially anxious. Motivation and Emotion,19 (1).

http://www.springerlink.com/content/pn01w833t4115270/

Warren, S., Huston, L., Egeland, B. \& Sroufe, L. (1997). Child and adolescent anxiety disorders and early attachment. http://en.wikipedia.org/wiki/Social_anxiety_disorder

Weinstock, L. S. (1999). Gender differences in the presentation and management of social anxiety disorder. Journal of Clinical Psychiatry, 60 (9), 9-13. http://www.ncbi.nlm.nih.gov/pubmed/10335674

Wittchen, H. U., Stein, M. B. \& Kessler, R. C. (1999). Social fears and social phobia in a community sample of adolescents and young adults: prevalence, risk factors and comorbidity. Psychological Medicine, 29, 309-323.

http://www.ncbi.nlm.nih.gov/pubmed/10218923

How to cite this article: S Gayatridevi, A Vincent (2016), Influencing Factors of Social Anxiety and Emotional Maturity among Adolescents, International Journal of Indian Psychology, Volume 3, Issue 4, No. 68, ISSN:2348-5396 (e), ISSN:2349-3429 (p), DIP:18.01.197/20160304, ISBN:978-1-365-39398-3 